King of the Night 


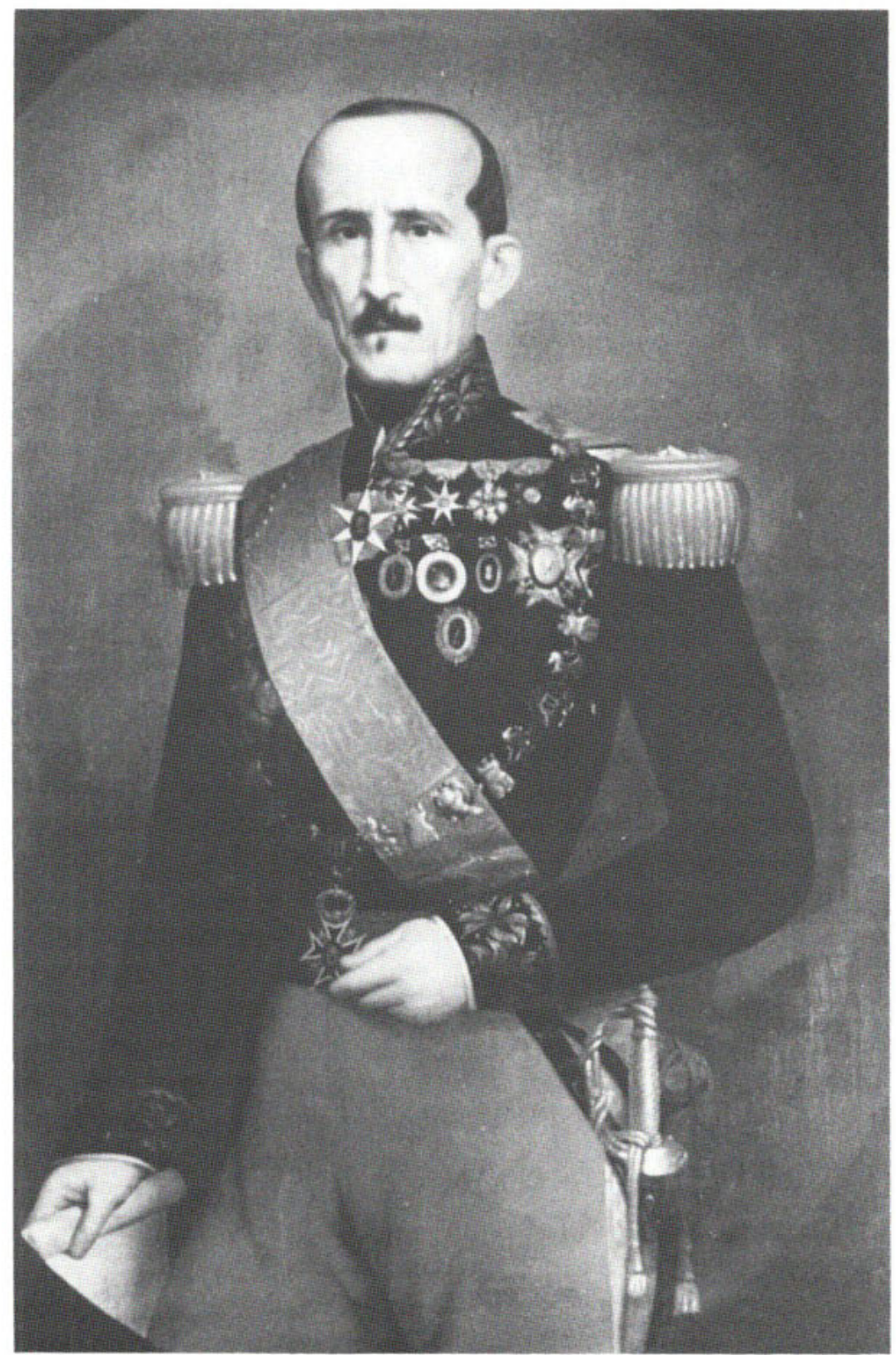

Oil painting of General Juan José Flores by Antonio Salas in Biblioteca Juan José Flores, at the Universidad Católica del Ecuador (Quito). Photograph by Mark J. Van Aken 


\title{
King of the Night Juan José Flores and Ecuador, 1824-1864
}

\author{
MARK J. VAN AKEN
}

UNIVERSITY OF CALIFORNIA PRESS Berkeley Los Angeles London 


\section{University of California Press \\ Berkeley and Los Angeles, California \\ University of California Press, Ltd. \\ London, England}

Copyright $\odot 1989$ by The Regents of the University of California

Library of Congress Cataloging-in-Publication Data

Van Aken, Mark J.

King of the night : Juan José Flores and Ecuador, 1824-1864 / Mark

J. Van Aken.

p. $\mathbf{c m}$.

Bibliography: p.

Includes index.

ISBN 0-520-06277-9 (alk. paper)

1. Flores, Juan José, 1800-1864-Views on monarchy. 2. Ecuador-

Politics and government-1830-1895. 3. Ecuador-Politics and

government-1809-1830. 4 Monarchy-Ecuador-History-19th century.

5. Ecuador-Relations-Foreign countries. I. Title.

F3736.F5V36 1989

986.6'05-dc19

88-20606

CIP

Printed in the United States of America

$\begin{array}{lllllllll}1 & 2 & 3 & 4 & 5 & 6 & 7 & 8 & 9\end{array}$ 


$$
\text { For }
$$

Dolores, Philip, Yoonhee, Leslie, and Kelly 
